\title{
LOW FAT RAS CHEESE WITH EXOPOLYSACCHARIDE PRODUCING STARTER CULTURES
}

Doaa M. Abd Allah ${ }^{1}$, Hagrass $^{2}$ A.E., Awad ${ }^{2}$ R.A. and Wafaa M. Salama ${ }^{1}$

1- Food Technology Research Institute, Agricultural Research Center, Giza, Egypt

2- Food Sci. Dept., Fac. of Agric., Ain Shams Univ., P.O. Box 68, Hadayek Shobra 11241, Cairo, Egypt

${ }^{*}$ Corresponding author: doaamaamoun151@gmail.com

\section{ABSTRACT}

Using of the exopolysaccharide-producing starter culture for improving the texture and technical properties of low-fat Ras cheese was studied. Ras cheese was manufactured using cow milk ( $3 \%$ fat) with non-producing- EPS starter as control $\left(\mathrm{C}_{\mathrm{F}}\right)$. Low fat cow milk (1.5\% fat) was divided into 3 equal portions. The first portion was served as control $\left(\mathrm{C}_{\mathrm{l}}\right)$ with non-producing- EPS starter. While EPS producing starter either commercial $\left(T_{1}\right)$ or laboratory $\left(T_{2}\right)$ were added for the other two portions respectively. The experimental design was performed to compare full and low fat Ras cheese $\left(\mathrm{C}_{\mathrm{F}}\right.$ and $\left.\mathrm{C}_{\mathrm{I}}\right)$ with non-producing- EPS starter culture with commercial and laboratory ( $\mathrm{T}_{1}$ and $\mathrm{T}_{2}$ ) with EPS producing starter culture. The physicochemical, textural profile analysis and organoleptic properties of fresh and stored cheeses (3 months) were determined. Also, the microscopic structural changes in fresh low- fat Ras cheese with EPSproducing starter were evaluated. The results indicated that addition of EPS producing cultures with decreasing fat of cheese milk lead to an increase in the moisture of treatments. Protein content of low fat Ras cheese was slight decreased with adding EPS-producing starter in cheese. The data indicate that control cheese (full fat without EPSproducing cultures) had the lowest values of acidity compared to low fat without EPS-producing cultures. Addition of exopolysaccharides starter in low fat Ras cheese caused decrease in hardness in cheeses. Values of hardness, cohesiveness, springiness, gumminess and chewiness decreased during storage period for 3 months. Using EPSproducing cultures in low fat Ras cheese was more pronounced on microscopic structural changes of the resultant cheese. Also, addition of EPSproducing cultures in Ras cheese milk improved sensory evaluation of the resultant cheese and cheese with $1.5 \%$ fat and EPS-producing culture $\left(T_{2}\right)$ was selected as the best cheese by sensory panel to produce high quality Ras cheese.

Keywords: Exopolysaccharides starter culture, low fat Ras cheese, Texture profile analysis (TPA) and organoleptic properties.

\section{INTRODUCTION}

Ras cheese, the main traditional hard cheese in Egypt is manufactured in a high proportion under artisan conditions from raw cow's or mixture of cow's and buffalo's milk without using starter cultures and marketed when it has a queried sharp flavour closed to kefalotyic cheese after 3 to 6 months [Hofi et al 1970; Scott, 1986; Phelan et al 1993]. Fat has an important role in the development of texture, flavour and appearance of cheese (Koca and Metin 2004). Textural attributes are believed to be important criteria in determining the identity and quality of a cheese and its consumer acceptability (Dabour et al 2006). Manufacturing low-fat or reduced-fat cheese with an acceptable flavour and texture demonstrates some difficulties as reported previously by many authors (Banks et al 1989, 1993; Jameson 1990; Anderson et al 1993; Bryant et al 1995). One of the major problems with fat reduction in cheese is the development of a firm texture that does not break down during mastication, unlike that observed in full-fat cheeses (Rogers et al 2010). Creamy mouth feel and texture provided by fat can be achieved by increasing the moisture content beyond that of full- 
fat cheese (Mistry 2001). Modifying cheese making procedures and/or using emulsifiers and thickening agents are the potential means of increasing moisture content in low-fat cheeses (Banks et al 1989; Chen and Johnson 1996).

Starter culture selection is one of the alternative ways to overcome problems associated with fat reduction. Using strains of lactic acid bacteria $(\mathrm{LAB})$ to produce an extracellular material called exopolysaccharide (EPS) in the growth medium could be an alternative for increasing the moisture content and improving sensory attributes of reduced and/or low-fat cheeses because EPS demonstrates some functional properties in food systems such as water-binding capacity, increase in viscosity and stabilization of body (Broadbent et al 2001; Ruas-Madiedo et al 2002; Amatayakul et al 2006; Dabour et al 2006; Costa et al 2010).

Studies aimed at producing low-fat cheeses generally show that low-fat products made by conventional methods have sensory defects, such as poor aroma, undesired flavours (a meaty or bitter taste) and a texture which is over firm, elastic (often described as 'rubbery'), or affected by crystallization of calcium lactate (Bryant et al 1995).

There is a general lack of information on the application of EPS-producing dairy starters in different varieties of reduced and/or low-fat cheeses especially low fat Ras cheese. Therefore, the objective of this study was to improve the sensory quality and high yield of low-fat Ras cheese using exopolysaccharide - producing cultures.

\section{MATERIALS AND METHODS}

\section{Materials}

Fresh cow milk was obtained from the Food Technology Research Institute, Agric. Res. Center, Giza, Egypt. Starter culture; which consists of Streptococcus salivarius subsp. thermophillus $\mathrm{CH}$ 1, Thermophilic culture Yoflex Express 1.0 EPSproducing cultures and Thermophilic culture Yoflex $\mathrm{CH}-1$ non EPS- producing cultures were obtained from Chr. Hanesn lab., Denmark and Lactobacillus delbruckii subsp. Bulgaricus DSM 20080 EPSproducing cultures were obtained from the Egyptian Microbial Culture Collection (EMCC), Cairo MIRCEN, Faculty of Agriculture, Ain Shams University, Cairo, Egypt. Rennet powder (Hanelase) was obtained from Chr. Hansen's Lab., Denmark. Fine cooking salt produced by EL-Naser Saline's Company was obtained from the local market.

\section{Cheese manufacture}

Ras cheese was manufactured according to Hofi et al (1970). Fresh cow milk was standardized to $~ 3 \%$ (full fat) and $1.5 \%$ (low fat), heated to $72^{\circ} \mathrm{C}$ for 15 seconds, then cooled to $35^{\circ} \mathrm{C}, 2 \%$ of yoghurt starter cultures containing Lactobacillus delbrueckii subsp. bulgaricus and Streptococcus thermophilus (1:1) was added.

Four different types of Ras cheeses were prepared as the following:-

$\mathrm{C}_{\mathrm{F}}$ : Full Fat $3 \%$ with non -producing EPS commerical starter culture of (Streptococcus thermophilus+ Lactobacillus bulgaricus 1:1).

$\mathrm{Cl}$ : Low Fat $1.5 \%$ with non -producing EPS commerical starter culture of (Streptococcus thermophilus+ Lactobacillus bulgaricus 1:1).

$\mathrm{T}_{1}$ : Low Fat $1.5 \%$ with producing EPS commercial starter culture of (Streptococcus thermophilus+ Lactobacillus bulgaricus 1:1).

$\mathrm{T}_{2}$ : Low Fat $1.5 \%$ with producing EPS laboratory starter culture of (Streptococcus thermophilus+ Lactobacillus bulgaricus 1:1).

Resultant cheese was stored at $15^{\circ} \mathrm{C} \pm 2$ for 3 month. All cheese treatments were sampled and analyzed when periodically at zero time, 30, 60 and 90 days for chemical, rheological, sensory properties and microstructure. The whole experiment was duplicated.

\section{Method of analysis}

\section{Chemical analysis}

Cheese samples were analyzed for moisture, total nitrogen (T.N), fat, salt, and titratable acidity (T.A) according to AOAC (2012). Total volatile fatty acids in Ras cheese samples were determined by the direct distillation method as described by Kosikowski (1984). Soluble tyrosine and tryptophan content were determined spectrophotometrically (values were expressed as $\mathrm{mg} / 100 \mathrm{~g}$ cheese) according to Vakaleris and Price (1966). Is scanning electron microscopy (SEM) following the method of Brooker and Wells (1984) was used. Texture profile analysis (TPA) of Ras cheese was measured at $23^{\circ} \mathrm{C}$ as described by Bourne (1982).

\section{Sensory analysis}

The organoleptic properties of ras cheese samples were assessed by a regular taste panels of experienced staff members at Food Science Department, Fac., Agric., Ain Shams University. 
Ras cheese samples were evaluated for flavour (50 points), body and texture (40 points) and appearance (10 points) according to Hofi et al (1970).

\section{Statistical analysis}

All data were analyzed by the General Linear Models procedure of SAS (1990). Least significant difference test was performed to determine differences in means at $\mathrm{P} \leq 0.05$.

\section{RESULTS AND DISCUSSION}

\section{Physiochemical characterization of low-fat Ras Cheese with expolysaccharide cultures}

Moisture content of fresh low fat Ras cheese as affected by using expolysacchride producing cultures (EPS) are shown in Table (1). The results indicate that cheese with low fat $\left(T_{2}\right)$ had the highest moisture content while low fat Ras cheese with non-producing- EPS $\left(\mathrm{C}_{\mathrm{l}}\right)$ had the lowest. Low-fat Ras cheese treatments with EPS ( $T_{1}$ and $\left.T_{2}\right)$ had higher moisture content compared to low-fat Ras cheese without EPS starter culture $\left(\mathrm{C}_{\mathrm{l}}\right)$. These changes due to retention of water in cheese curd depending on EPS-producing capacity of the cultures (Sanli et al 2013). The results are in agreement with those reported by El-Soda (2014).

Table 1. Chemical composition of fresh low fat Ras cheese treatments without \& with exopolysaccharides producing cultures

\begin{tabular}{|l|c|c|c|c|}
\hline \multirow{2}{*}{$\begin{array}{c}\text { Character } \\
\text { assessed }\end{array}$} & \multicolumn{4}{|c|}{ Treatments $^{*}$} \\
\cline { 2 - 5 } & $\mathbf{C}_{\mathbf{F}}$ & $\mathbf{C}_{\mathrm{I}}$ & $\mathbf{T}_{1}$ & $\mathbf{T}_{\mathbf{2}}$ \\
\hline \multicolumn{5}{|c|}{ Fresh } \\
\hline Moisture & $38.26^{\mathrm{B}}$ & $36.94^{\mathrm{C}}$ & $38.78^{\mathrm{B}}$ & $40.21^{\mathrm{A}}$ \\
T.N (\%) & $3.30^{\mathrm{B}}$ & $4.42^{\mathrm{A}}$ & $4.35^{\mathrm{A}}$ & $4.33^{\mathrm{A}}$ \\
Fat (\%) & $26.00^{\mathrm{A}}$ & $13.50^{\mathrm{B}}$ & $13.40^{\mathrm{B}}$ & $13.30^{\mathrm{BC}}$ \\
Salt(\%) & $4.91^{\mathrm{B}}$ & $5.18^{\mathrm{A}}$ & $5.09^{\mathrm{A}}$ & $4.98^{\mathrm{B}}$ \\
\hline
\end{tabular}

$\mathrm{C}_{\mathrm{F}}$ : Full Fat $3 \%$ with non -producing EPS commerical starter culture of (Str.thermophilus+Lacto.bulgaricus 1:1) * $\mathrm{C}_{\mathrm{l}}$ : Low Fat $1.5 \%$ with non -producing EPS commerical starter culture of (Str.thermophilus+Lacto.bulgaricus 1:1). $\mathrm{T}_{1}$ : Low Fat $1.5 \%$ with producing EPS commercial starter culture of (Str.thermophilus+Lacto.bulgaricus 1:1).

$\mathrm{T}_{2}$ : Low Fat $1.5 \%$ with producing EPS laboratory starter culture of (Str.thermophilus+Lacto.bulgaricus 1:1).

$A, B, C$ : Means with the same letter among treatments are not significantly different.
The data showed that, the using of EPSproducing cultures in low fat cheese led to decrease fat and total nitrogen content compared to low fat Ras cheese $\left(\mathrm{Cl}_{\mathrm{l}}\right)$. Dabour et al (2006) reported that protein content of EPS-containing cheeses were significantly low than that of control cheese (without EPS cultures ) and appeared to be proportionally affected by the amount of water retained in cheese. The salt contents followed the same trend to that of total nitrogen content.

The changes in titratable acidity of low -fat Ras cheese with EPS-producing cultures during storage period are illustrated in Fig. (1). The data indicate that control cheese (full-fat $\left(C_{F}\right)$ without EPSproducing cultures) had low values of acidity compared to low fat without EPS-producing cultures $\left(\mathrm{Cl}_{\mathrm{I}}\right.$. Low-fat Ras cheese made with adding EPSproducing cultures $\left(\mathrm{T}_{2}\right)$ had the low acidity values among treatments. This could be attributed to the high moisture content of this treatment $\left(\mathrm{T}_{2}\right)$.Our results are in agreement with Tohamy et al (2011) who stated that the acidity of low-fat Ras cheese was decreased compared with full-fat Ras cheese (control).All values of acidity increased with prolonging the storage period. The increase in acidity value at the end of storage was different to that of fresh samples. The general trend of these results is in agreement with those reported by Tohamy et al (2011).

Results in Fig. (2) illustrate that low fat Ras cheese $\left(\mathrm{Cl}_{\mathrm{l}}\right)$ developed $4.50 \mathrm{ml}$ of total volatile fatty acids (TVFA) per $100 \mathrm{~g}$. on the first day of production, in comparison with 5.94 and $5.92 \mathrm{ml}$ for both commercial and laboratory starter cheese respectively $\left(T_{1} \& T_{2}\right)$. The total volatile fatty acids in full fat cheese $\left(\mathrm{C}_{\mathrm{F}}\right)$ were the highest value which could be attributed to its higher content of fat (Table 1). However, reduction of fat in cheese may cause a lower amount of fatty acids due to the cheese may perceive as lacking flavour (Mistry 2001). General, using EPS-producing cultures either commercial or laboratory in low Ras cheese improved the TVFA of Ras cheese compared to low fat Ras cheese control $\left(\mathrm{C}_{\mathrm{l}}\right)$ (Hassan 2005). The total volatile fatty acids have increased continuously the ripening period, but they increased more quickly in the full fat Ras cheese control $\left(\mathrm{C}_{\mathrm{F}}\right)$.

The changes in soluble tyrosine and soluble tryptophan values for all cheese treatments including two controls $\left(\mathrm{C}_{\mathrm{F}}, \mathrm{C}_{\mathrm{l}}\right)$ when fresh and during storage period (90 days) followed simaller trend to that of TVFA. 


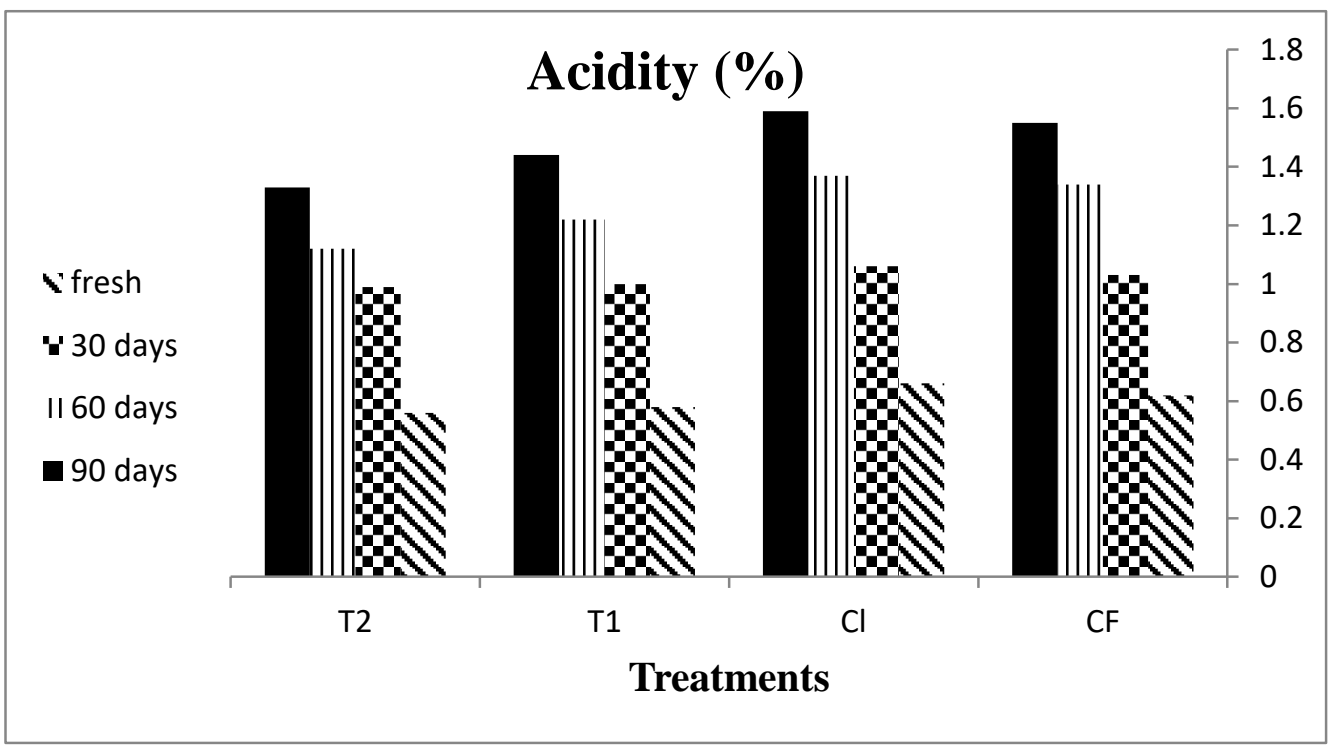

Fig. 1. Titratable acidity of low fat Ras cheese treatments* without \& with exopolysaccharides producing cultures when fresh and during ripening period.

*see Table (1).

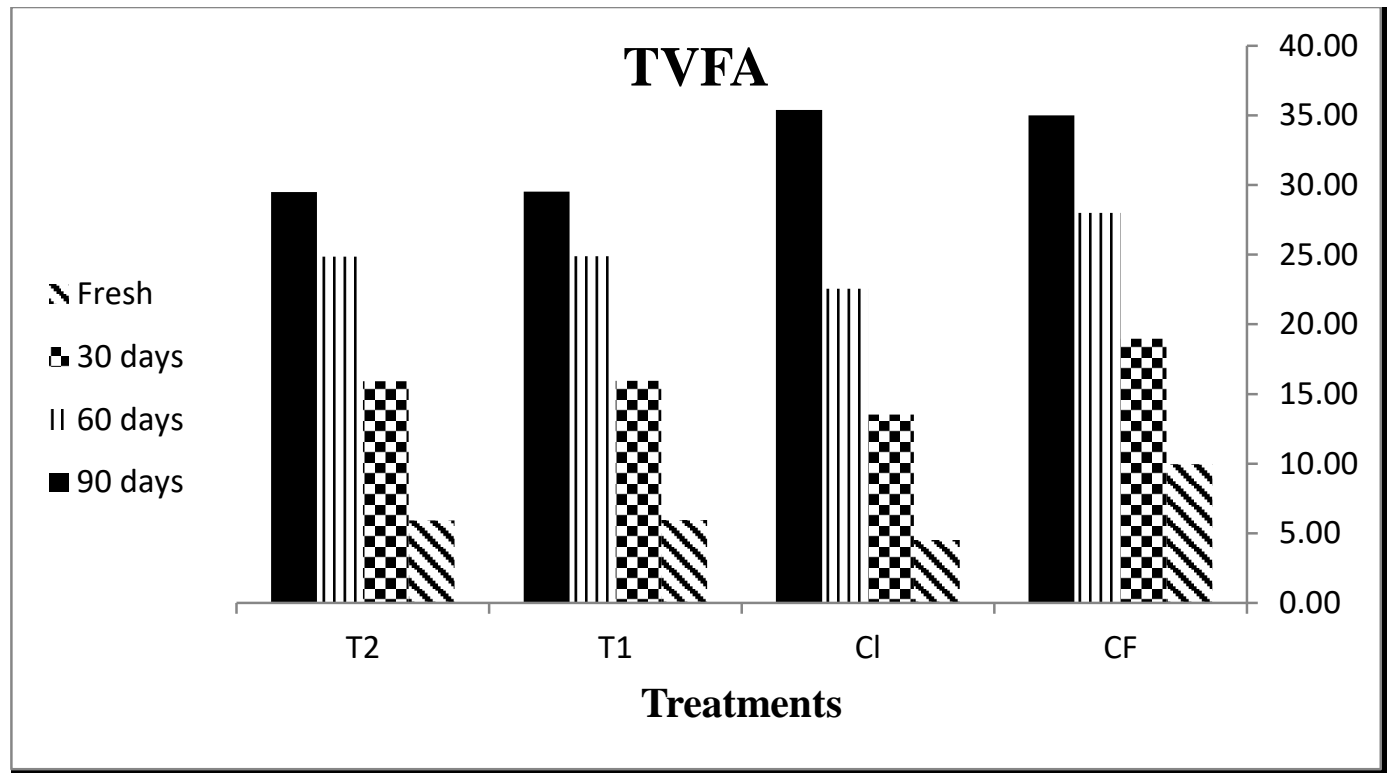

Fig. 2. TVFA ( $\mathrm{ml} 0.1 \mathrm{NNaOH} / 100 \mathrm{~g}$ ) of low fat Ras cheese treatments* without\&with exopolysaccharides producing cultures when fresh and during ripening period.

${ }^{*}$ see Table (1). 


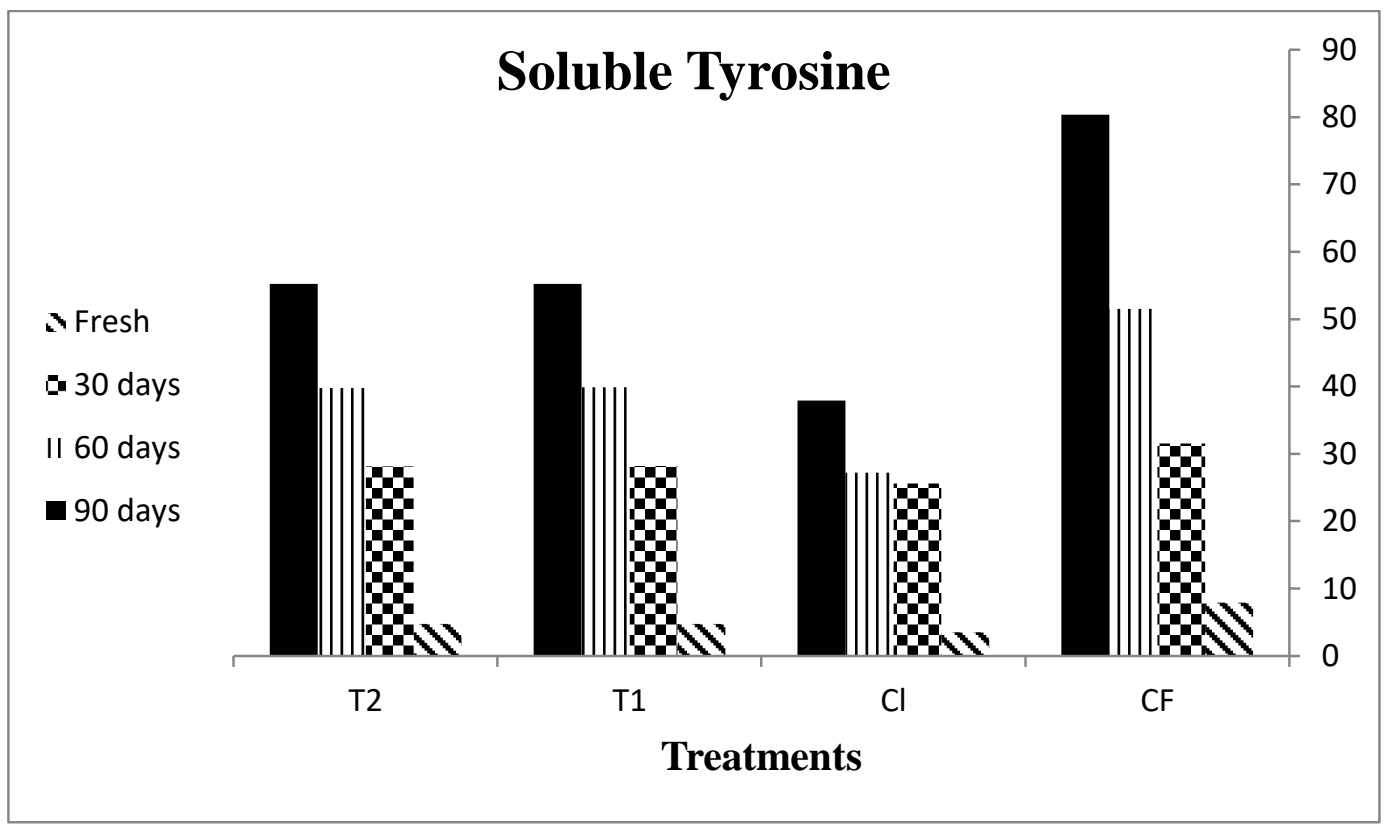

Fig. 3. SolubleTyrosine $(\mathrm{mg} / \mathrm{100 \textrm {g }}$ ) of low fat Ras cheese treatments* without\&with exopolysaccharides producing cultures when fresh and during ripening period. *see Table (1).

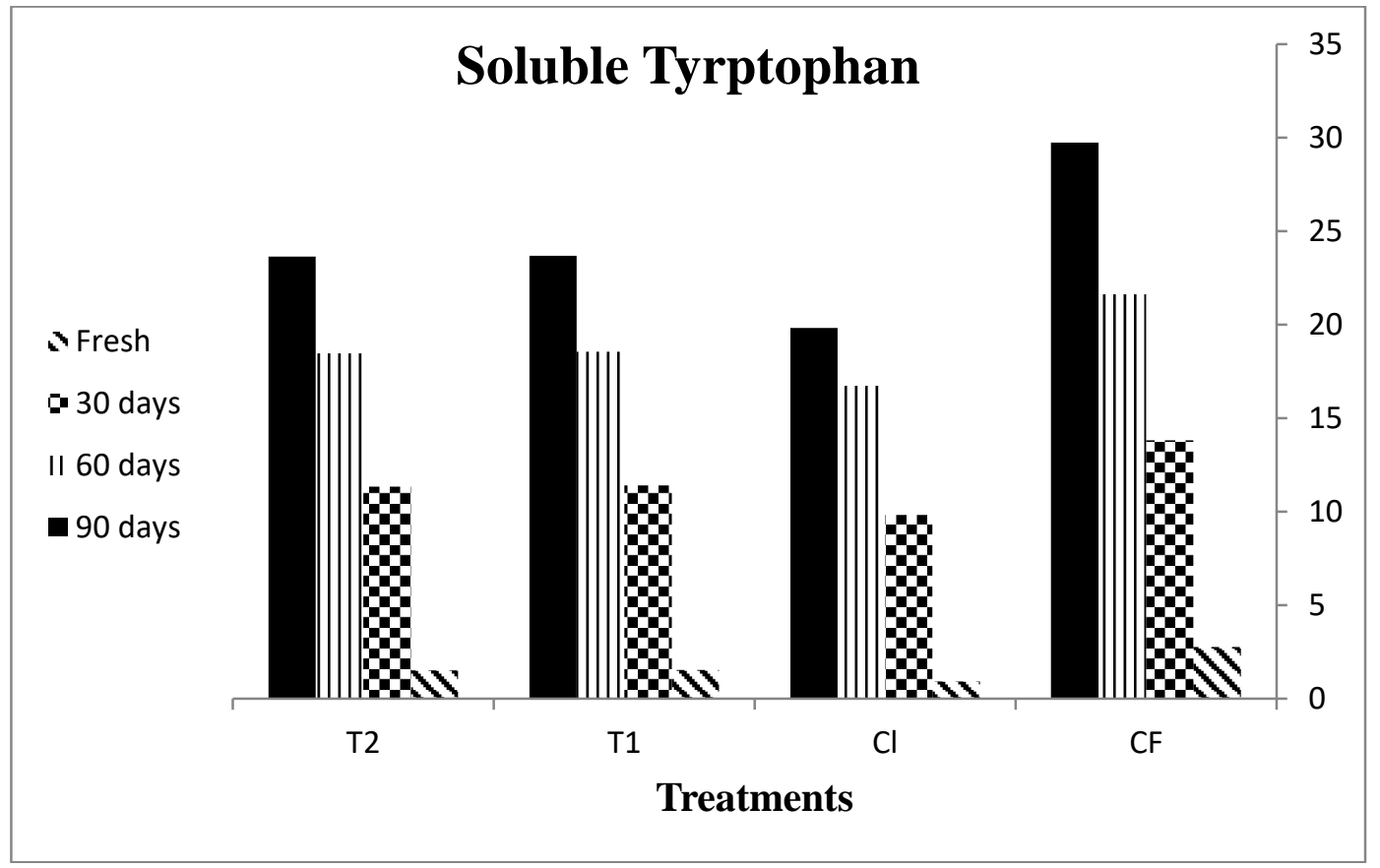

Fig. 4. SolubleTryptophan $(\mathrm{mg} / 100 \mathrm{~g}$ ) of low fat Ras cheese treatments* without\&with exopolysaccharides producing cultures when fresh and during ripening period. *see Table (1). 


\section{Texture profile analysis}

Hardness is described as the force required to penetrate the sample with the molar teeth (from soft to firm) Lee et al (1978). From the obtained results (Table 2) it could be seen that, addition of exopolysaccharides starter in low fat cheese caused decrease in hardness in cheeses. This may be due to replace non- producing with producing exopolysaccharides starter added led to increase in cheese moisture content, as a result of water adsorption or binding by exopolysaccharides starter. There were more factors affect on the curd moisture content (temperature of coagulation and drain of whey), cheese composition, $\mathrm{pH}$, interactions between casein and serum proteins, Ca content, ionic strength, salt content, and manufacturing protocol, especially rate and extent of acid development. Fat content in the cheese is responsible for its many desirable functional and texture. In addition, decreasing moisture content might result in decrease in the level of free moisture in cheese; this increased the hardness (Awad, 2011). Because the increase in moisture content weakness the casein micelles. Springiness is described to the panelists as bouncing properties of the sample through several consecutive bites. The obtained values of this property (Table 2) for treatments low fat Ras cheese including control $\left(\mathrm{C}_{\mathrm{l}}\right)$ ranged from 3.47 to $4.10 \mathrm{~mm}$ which meaning that the hardness decreased. Cohesiveness known as the degree to which the cheese treatments deforms before rupturing, therefore, cohesiveness values is a direct function of the work needed to overcome the internal bonds of the material. Gumminess and chewiness values had the same direction of hardness and cohesiveness. Treatment $\left(T_{2}\right)$ with exopolysaccharides laboratory starter showed the lowest in hardness, Gumminess and chewiness compared to other treatment including two controls $\left(\mathrm{C}_{\mathrm{F}}, \mathrm{C}_{\mathrm{l}}\right)$. Chewiness is described to be the number of chews required to swallow a certain amount of sample. This property expressed mathematically as the product of gumminess \& springiness, therefore, it took the same trend of these property. Values of hardness, cohesiveness, springiness, gumminess and chewiness decrease during storage period for 3 months.
Table 2. Texture profile analysis of low fat Ras cheese treatments without\&with exopolysaccharides producing cultures when fresh and during ripening period.

\begin{tabular}{|l|c|c|c|c|}
\hline \multirow{2}{*}{ Character assessed } & \multicolumn{4}{|c|}{ Treatments $^{*}$} \\
\cline { 2 - 5 } & $\mathbf{C}_{\mathbf{F}}$ & $\mathbf{C}_{\mathbf{l}}$ & $\mathbf{T}_{\mathbf{1}}$ & $\mathbf{T}_{\mathbf{2}}$ \\
\hline \multicolumn{5}{|c|}{ Fresh } \\
\hline Hardness (N) & 21.4 & 28.7 & 18.9 & 13.4 \\
Adhesiveness (mJ) & 1.280 & 1.381 & 0.544 & 0.566 \\
Cohesiveness (Ratio) & 0.28 & 0.24 & 0.36 & 0.43 \\
Springiness (mm) & 4.22 & 3.47 & 4.10 & 3.88 \\
Gumminess (N) & 6.0 & 6.8 & 6.7 & 5.8 \\
Chewiness (mJ) & 25.27 & 23.48 & 27.53 & 22.46 \\
\hline \multicolumn{5}{|c|}{ After 30 days } \\
\hline Hardness (N) & 41.3 & 49.2 & 26.7 & 24.7 \\
Adhesiveness (mJ) & 0,282 & 0.284 & 0.069 & 1.487 \\
Cohesiveness (Ratio) & 0.68 & 0.70 & 0.73 & 0.37 \\
Springiness (mm) & 7.56 & 7.40 & 8.69 & 5.83 \\
Gumminess (N) & 28.3 & 34.3 & 19.4 & 9.0 \\
Chewiness (mJ) & 213.87 & 253.66 & 168.55 & 52.57 \\
\hline \multicolumn{5}{|c|}{ After 60 days } \\
\hline Hardness (N) & 59.4 & 61.4 & 49.5 & 46.8 \\
Adhesiveness (mJ) & 1.381 & 0.699 & 0.103 & 0.316 \\
Cohesiveness (Ratio) & 0.22 & 0.40 & 0.30 & 0.72 \\
Springiness (mm) & 3.23 & 4.66 & 3.83 & 6.30 \\
Gumminess (N) & 13.2 & 24.6 & 14.7 & 33.5 \\
Chewiness (mJ) & 42.64 & 114.86 & 56.18 & 210.94 \\
\hline \multicolumn{5}{|c|}{ After 90 days } \\
\hline Hardness (N) & 35.4 & 45.6 & 20.9 & 20.2 \\
Adhesiveness (mJ) & 0.082 & 0.398 & 1.295 & 0.073 \\
Cohesiveness (Ratio) & 0.29 & 0.53 & 0.23 & 0.80 \\
Springiness (mm) & 5.16 & 6 & 2.84 & 7.99 \\
Gumminess (N) & 10.4 & 24.1 & 4.9 & 16.2 \\
Chewiness (mJ) & 53.70 & 144.44 & 13.93 & 129.19 \\
\hline See Table (1)
\end{tabular}

* See Table (1)

\section{Microscopic Structural Changes}

The microscopic structural changes in fresh low- fat Ras cheese without\&with EPS-producing starter are shown in Fig. (5). The protein matrix (gray area) formed a continuous phase permeated by an amorphous system of voids filled with serum (black area), which in turn revealed the spatial dimensions of these images. Fat reduction is associated with many textural and functional defects in cheese (Mistry, 2001). The high casein content in 
reduced-fat cheese imparts a firm and rubbery body and texture (Mistry, 2001). Casein micelles aggregate to form a protein network in which the fat globules are entrapped (Ong et al 2013). The microstructure of milk proteins matrix changes during processing of cheese according to the type of starter and content of milk fat. An extremely porous, open, was obtained in full-fat Ras cheese $\left(C_{F}\right)$, whereas a continuous phase of protein aggregate network characterized by a more compacted and dense structure accompanied by less voids was revealed in the low fat Ras cheese $\left(\mathrm{Cl}_{\mathrm{l}}\right)$ reflecting the hardness texture that was revealed by sensory evaluation. As it might be seen in Fig. (5) the using 1.5\% fat and replacing of non
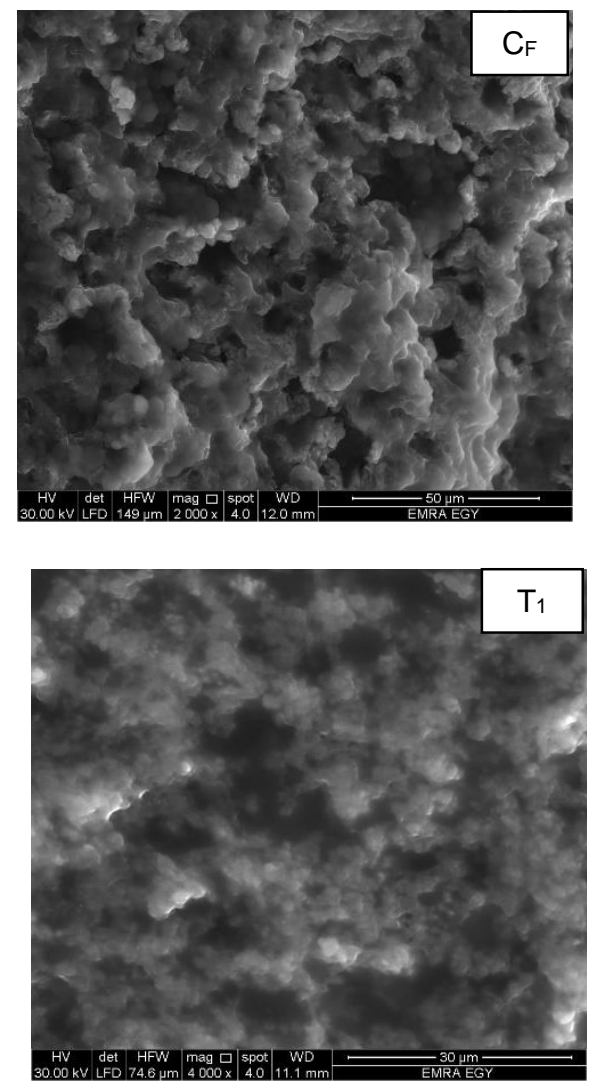

producing EPS starter with EPS-producing culture either commercial or laboratory in low fat Ras cheese (Fig. $5 \mathbf{T}_{1}, \mathbf{T}_{2}$ ) promoted regularly aggregated protein matrices characterized by a finemeshed network accompanied by small pores that was much smaller in size compared to that of control low fat Ras cheese (Fig. $5 \mathbf{C}_{\mathbf{l}}$ ). Treatment cheese, $T_{2}$ showed many big pores maybe cause the higher moisture in this cheese. It had an open structure that resembled the control cheese. Generally, using EPS-producing cultures either commercial or laboratory in low- fat Ras cheese were more pronounced on microscopic structural changes of the resultant cheese.
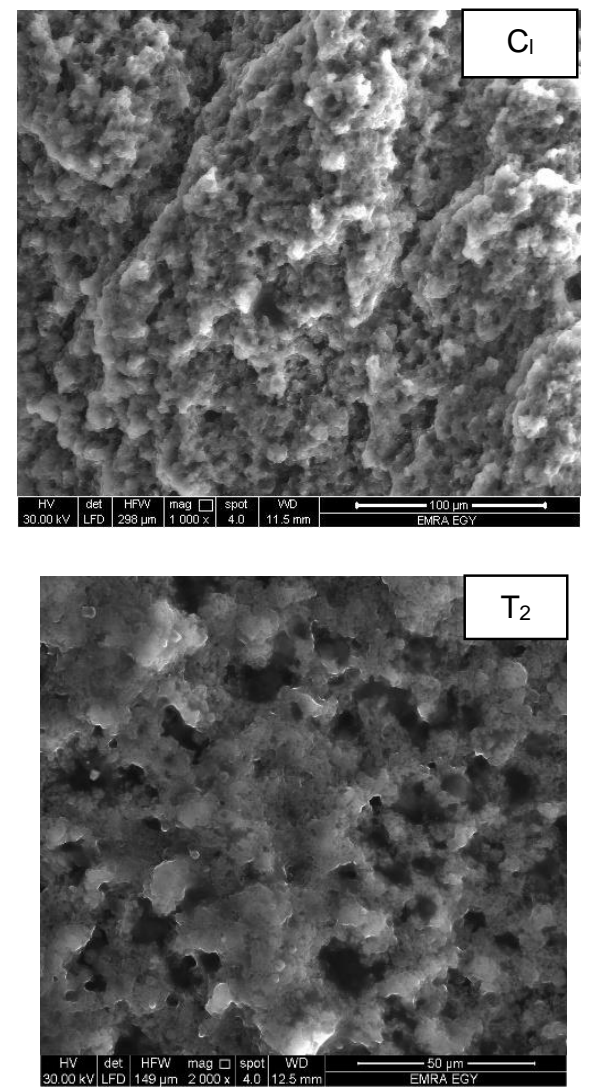

Fig. 5. Scanning electron micrographs (SEM) of fresh Ras cheese as affected by using exopolysaccharide. $\mathrm{C}_{\mathrm{F}}$ : Full Fat $3 \%$ with non -producing EPS commerical starter culture of (Str. Thermophiles + Lacto. bulgaricus 1:1).

$\mathrm{C}_{\mathrm{l}}$ : Low Fat $1.5 \%$ with non -producing EPS commerical starter culture of (Str. thermophile $s+$ Lacto. bulgaricus 1:1).

$\mathrm{T}_{1}$ : Low Fat $1.5 \%$ with producing EPS commercial starter culture of (Str. thermophiles + Lacto. bulgaricus $1: 1)$.

$\mathrm{T}_{2}$ : Low Fat $1.5 \%$ with producing EPS laboratory starter culture of (Str. thermophiles + Lacto. bulgaricus $1: 1)$. 
Results from sensory evaluation of Ras cheeses during ripening are given in Table (3). The flavour points for Ras cheeses were significantly ( $P$ $<0.05$ ) affected using EPS-producing cultures. lowfat with non- EPS producing culture cheese received significantly lower flavour scores than the full fat control $\left(\mathrm{C}_{\mathrm{F}}\right)$ when fresh and during ripening. Reduction of fat in cheese may cause a lower amount of fatty acids due to the cheese may perceive as lacking flavor (Mistry 2001). Flavor scores in Ras cheeses were rapidly increased by the age of 90 days of ripening. Cheeses made using the EPS-producing cultures either commercial or laboratory ( $T_{1}$ and $T_{2}$ ) were described as smooth and soft. However Ras cheese with low fat $\left(\mathrm{Cl}_{\mathrm{l}}\right)$ was described as dry texture. Similar results were found by Ahmed et al (2005) for Karish cheese made using EPS-producing cultures. The body and texture scores in full and low - fat cheeses including EPS-producing cultures ( $T_{1}$ and $\mathrm{T}_{2}$ ) had higher points than those of the cheeses 1ow fat control $\left(\mathrm{C}_{\mathrm{I}}\right)$. Low-fat cheeses are typically characterized as weak and rough texture as described by Kosikowski and Mistry (1997) and the greater fat reduction gave the more defects (Banks et al 1993). A small degree of casein breakdown is required for body and texture development and an acceptable functionality. The more water content of the EPS-producing cultures cheeses changed its sensory characteristics, giving a softer texture for product (Jimenez-Guzman et al 2009). There were non significant differences noted in appearance scores between full fat and treated cheeses ( $T_{1}$ and $T_{2}$ ) compared to low fat without EPS-producing cultures cheese $\left(C_{l}\right)$ at the beginning and during of ripening period. Generally, the appearance, body and texture and flavour scores significantly increased in all cheeses during ripening.

In conclusion, using EPS-producing cultures either commercial or laboratory in low fat Ras cheese manufacture improved sensory evaluation of the resultant cheese. Cheese with $1.5 \%$ fat and EPS-producing laboratory culture $\left(\mathrm{T}_{2}\right)$ selected as the best cheese by sensory panels to produce high quality Ras cheese.
Table 3. Sensory evaluation of low fat Ras cheese treatments without \& with exopolysaccharides producing cultures when fresh and during ripening period.

\begin{tabular}{|c|c|c|c|c|}
\hline \multirow{2}{*}{ Character assessed } & \multicolumn{4}{|c|}{ Treatments* } \\
\hline & $\mathbf{C}_{\mathrm{F}}$ & $\mathbf{C}_{\mathrm{I}}$ & $\mathrm{T}_{1}$ & $T_{2}$ \\
\hline \multicolumn{5}{|c|}{ Fresh } \\
\hline Flavour (50) & $46^{\mathrm{Aab}}$ & $40^{\mathrm{Bd}}$ & $46^{\mathrm{Aab}}$ & $46^{\mathrm{Aab}}$ \\
\hline Body \&texture (40) & 37 Aab & $30^{\mathrm{BC}}$ & $37^{\mathrm{Aab}}$ & 38 Aab \\
\hline Appearance (10) & $9^{A a}$ & $6^{\text {Bab }}$ & $9^{\mathrm{Aa}}$ & $9 \mathrm{Aa}$ \\
\hline Total Score (100) & $92^{\mathrm{Abc}}$ & $76^{\mathrm{Bc}}$ & $92^{\mathrm{Abc}}$ & $93^{A b}$ \\
\hline \multicolumn{5}{|c|}{ After 30days } \\
\hline Flavour (50) & $47^{\mathrm{Aab}}$ & $41^{\mathrm{Bc}}$ & $47^{\mathrm{Aab}}$ & $47^{A a b}$ \\
\hline Body \&texture (40) & 38 Aab & $34^{\mathrm{Bb}}$ & $38^{A a b}$ & $39 \mathrm{Aa}$ \\
\hline Appearance (10) & $10^{\mathrm{Aa}}$ & $7^{\text {Bab }}$ & $9^{\mathrm{Aa}}$ & $10^{\mathrm{Aa}}$ \\
\hline Total Score (100) & $95^{\mathrm{Aab}}$ & $82^{\mathrm{Bd}}$ & $94^{\mathrm{ABb}}$ & 96 Aab \\
\hline \multicolumn{5}{|c|}{ After 60 days } \\
\hline Flavour (50) & $48^{\mathrm{Aa}}$ & $45^{\mathrm{Bb}}$ & $48^{\mathrm{Aa}}$ & $44^{\mathrm{Aa}}$ \\
\hline Body \&texture (40) & $39 \mathrm{Aa}$ & $36^{\text {Bab }}$ & 38 ABab & $40^{\mathrm{Aa}}$ \\
\hline Appearance (10) & $10^{\mathrm{Aa}}$ & $7^{\text {Bab }}$ & $9^{A a}$ & $10^{\mathrm{Aa}}$ \\
\hline Total Score (100) & $97 \mathrm{Aa}$ & $88^{\mathrm{Cc}}$ & $95^{\mathrm{Bab}}$ & $98 \mathrm{Aa}$ \\
\hline \multicolumn{5}{|c|}{ After 90 days } \\
\hline Flavour (50) & $49 \mathrm{Aa}$ & $46^{\mathrm{ABab}}$ & $49 \mathrm{Aa}$ & $49 \mathrm{Aa}$ \\
\hline Body \&texture (40) & $39 \mathrm{Aa}$ & $36^{\text {Bab }}$ & $39 \mathrm{Aa}$ & $39 \mathrm{Aa}$ \\
\hline Appearance (10) & $10^{\mathrm{Aa}}$ & $7^{\mathrm{Bab}}$ & $9^{\mathrm{Aa}}$ & $10^{\mathrm{Aa}}$ \\
\hline Total Score (100) & $98^{\mathrm{Aa}}$ & $89 \mathrm{Bc}$ & $97^{\mathrm{Aa}}$ & $99 \mathrm{Aa}$ \\
\hline
\end{tabular}

* See Table (1) *

$A, B, C$ : Means with the same letter among treatments are not significantly different.

\section{REFFERNCES}

Ahmed N.H., El-Soda M., Hassan A.N. and Frank J. 2005. Improving the textural properties of an acid- coagulated (Karish) cheese using exopolysaccharide producing cultures. LMT- Food Sci. and Technology, 38, 843847. 
Amatayakul T., Sherkat F. and Shah N.P. 2006. Physical characteristics of set yoghurt made with altered casein to whey protein rations and EPS-producing starter cultures at 9 and 14\% total solids. Food Hydrocolloids, 20, 314324.

Anderson D.L., Mistry V.V., Brandsma R.L. and Baldwin K.A. 1993. Reduced fat Cheddar cheese from condensed milk: manufacture, composition and ripening. J. of Dairy Sci., 76, 2832-2844.

AOAC 2012. Association of Official Analytical Chemists official Methods of Analysis. Washington, P.C., USA.

Awad S. 2011. Texture and Microstructure. In Practical Food and Research. (Ed. Rui M.S. Cru), Nova Science publishers, Inc. pp. 361391.

Banks J.M., Hunter E.A. and Muir D.D. 1993. Sensory properties of low fat Cheddar cheese: effect of salt content and adjunct culture. J. of the Society of Dairy Technology, 46, 119123.

Banks J.M., Brechany E.Y. and Christie W.W. 1989. The production of low fat Cheddar-type cheese. Int. J. of Dairy Technology, 42, 6-9.

Bourne M.C. 1982. Texture profile analysis. Food Technology, 32, 62-72.

Broadbent J.R., McMahon D.J., Oberg C.J. and Welker D.L. 2001. Use of exopolysaccharideproducing cultures to improve functionality of low fat cheese. Int. Dairy J., 11, 433-439.

Brooker B.E. and Wells K. 1984. Preparation of dairy products for scanning electron microscopy : etching of epoxy resin-embedded material. J. Dairy Res, 51, 605-613.

Bryant A., Ustunol Z. and Steffe J. 1995. Texture of Cheddar cheese as Influenced by fat reduction. J. of Food Sci., 60(6), 1216-1236.

Chen C.M. and Johnson M.E. 1996. Process for manufacturing reduced fat Cheddar cheese. United States Patent No. 5554398, September 10.

Costa N.E., Hannon J.A., Guinee T.P., Auty M.A.E., McSweeney P.L.H. and Bereford T.P. 2010. Effect of exopolysaccharide produced by isogenic strains of Lactcoccus lactis on half-fat Cheddar cheese. J. of Dairy Sci., 93, 3469-3486.
Dabour N., Kheadr E.E., Benhamou N., Fliss I. and LaPointe G. 2006. Improvement of texture and structure of reduced-fat Cheddar cheese by exopolysaccharide-producing Lactocci. J. of Dairy Sci., 89, 95-110.

Hofi A.A., Yossef E.H., Ghoneim M.A., and Tawab G.A. 1970. Ripening changes in Cephalotyre "Ras" cheese manufactured fromraw and pasteurized milk with special reference to flavour. J. of Dairy Sci., 53, 12071212.

Hassan S.A.M. 2005. Improving the quality and microstructure of low fat Edam cheese made from buffaloe's milk. M.Sc. Theses, Cairo Univ., Egypt.

Jameson G.W. 1990. Cheese with less fat. Australian J. of Dairy Technology, 45, 93-98.

Jimenez-Guzman J. Flores-Najera A., CruzGuerrero A.E. and Garcia Garibay M. 2009. Use of an exopolysaccharide-producing strain of Streptococcus thermophilus in the manufacture of Mexican Panela cheese. LWT-Food Sci. and Technology, 42, 1508-1512.

Koca N. and Metin M. 2004. Textural, melting and sensory properties of low-fat fresh Kasar cheeses produced by using fat replacers. Int. Dairy J., 14, 365-373.

Kosikowski F.V. and Mistry V.V. 1997. Cheese and Fermented Milk Foods. Vol. 1. Origins and Principles. $3^{\text {rd }}$ Ed., Westport, CT: F.V. Kosikowski LLC.

Kosikowski F.V. 1984. Cheese and fermented milk foods. $2^{\text {nd }}$ Ed., printing Brooktonalds, New York 14817, USA.

Lee C.H., Imoto E.M. and Rha C. 1978. Evaluation of cheese texture. J. Food Sci., 43, 1600.

Mistry V.V. 2001. Low fat cheese technology. Int. Dairy J., 11, 413-422.

Morsi El-Soda 2014. Production of Low Fat Cheddar Cheese Made Using Exopolysaccharide-Producing Cultures and Selected Ripening Cultures. Advances in Microbiology, 4, 986-995.

Ong L., Raymond R. Dagastine, Sandra E. Kentish and Sally L. Gras 2013. Microstructure and Composition of Full Fat Cheddar Cheese Made with Ultrafiltered Milk Retentate. Foods, 2(3), 310-331. 
Phelan J.A. Renaud and Fox P.F. 1993. Some non-Euro - pean cheese varieties in cheese chemistry, physics and microbiology, Vol. 2. $2^{\text {nd }}$ Edn., Fox, P.E. ed. Chapman \& Hall, London, UK, pp. 421-465.

Rogers N.R., McMahon D.J., Daubert C.R., Berry T.K. and Foegeding E.A. 2010. Rheological properties and microstructure of Cheddar cheese made with different fat contents. J. of Dairy Sci., 93, 4565-4576.

Ruas-Madiedo P., Hugenholtz J. and Zoon P. 2002. An overview of the functionality of exopolysaccharides produced by lactic acid bacteria. Int. Dairy J., 12, 163-171.

Şanli T., Gursel A., Şanli E., Acar E. and Benli M. 2013. The effect of using an exopolysaccharide-producing culture on the physicochemical properties of lowfat and reduced-fat
Kasar cheeses. Int. J. of Dairy Technology, 66, 535-542.

SAS Institute 1990. SAS User's Guide/STAT ver. 6.04 Fourth edition SAS Inst. Inc., Cary, NC, USA.

Scott R. 1986. Cheese making practice $\left(2^{\text {nd }}\right.$ edn.), Elsevier Applied Science Publisher, Ltd, London, UK.

Tohamy M.M., El-Nawawy M.A., Kandeel A.A. and Moustafa M.A. 2011. Modification of the traditional method of making ras cheese, and its effect on the properties and quality of the resultant low-fat ras cheese. J. Food and Dairy Sci., Mansoura Univ., 2(3), 101-114.

Vakaleris D.G. and Price W.V. 1966. A rapid spectrophotometeric method for measuring cheese ripening. J. Dairy Sci., 47, 264. 


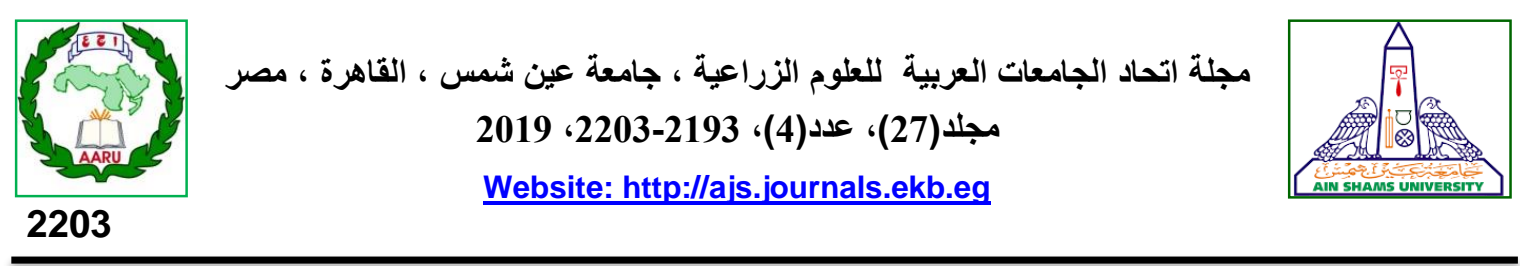

جبن أس منذفض الدهن بمزارع البادئات المنتجة للسكريات العديدة

[174]

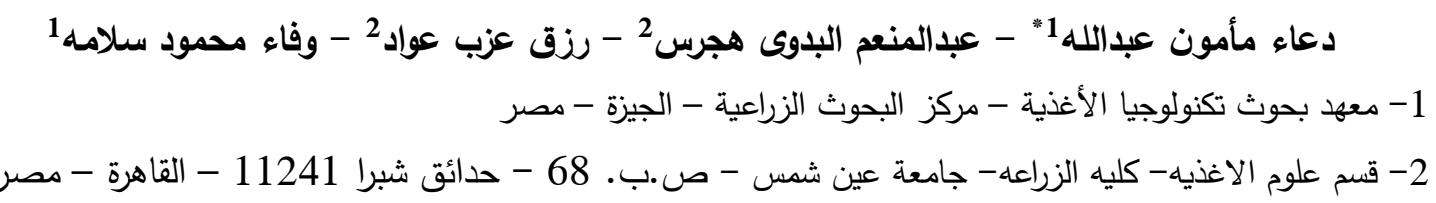

${ }^{*}$ Corresponding author: doaamaamoun151@gmail.com

Received 17 September, 2019

للجبن. تشير النتائج الى ان الجبن المقارنة (EPS)

(كامل الدهن بدون أضافة EPS) كان له أله أقل قير المقانة

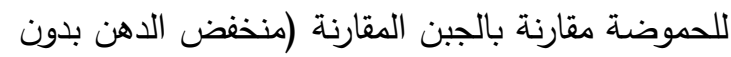

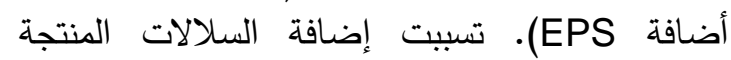

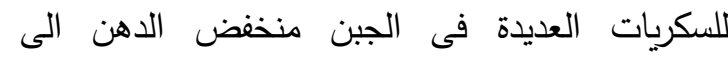

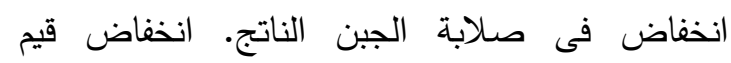

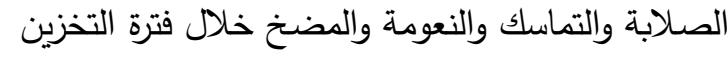
لمدة ثلاثة شهور • كان تأثير البادئات المنتجة (EPS)

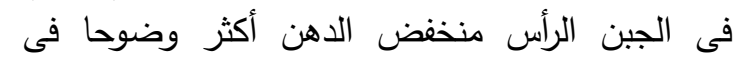

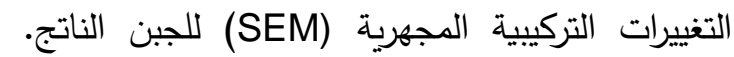

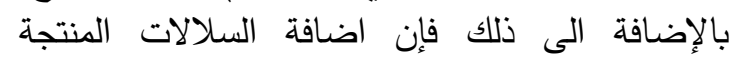
للجبن الرأس أدت الى تحسين فى التى التييم (EPS)

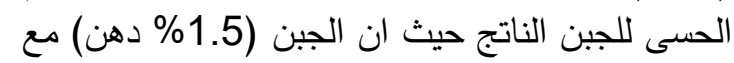
أستخدام السلالات المعملية (T2) تم أختيارها كأفضل التصن

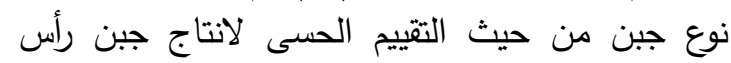

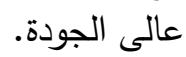

الكلمات الدالة: مزارع البادئات الدنتجة للسكريات

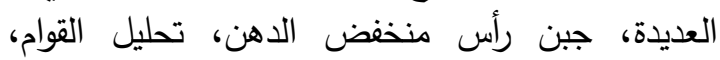

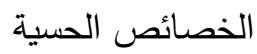

Accepted 4 November, 2019
تم دراسة أستخدام مزارع البادئات المنتجة للسكريات

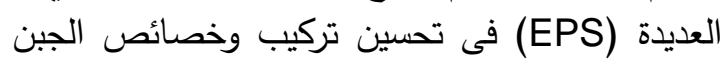
الرأس منخفض الدهن. حيث تم تصني تصنيع جبن تركين رأس من

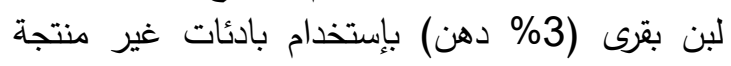

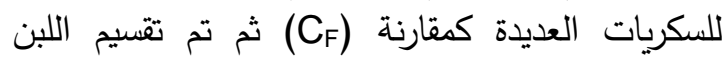
البقرى منخفض الدهن (1.5\% دهن) الى الى 3 أجزاء

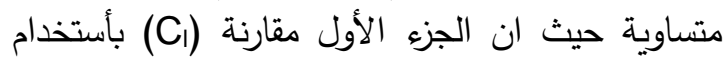

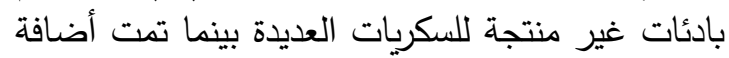

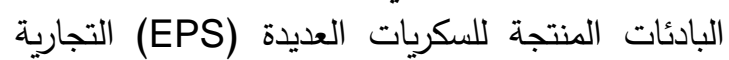
(T/1) للجزئين الأخرين على التواتية (T2)

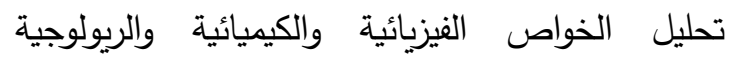

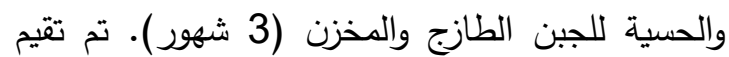

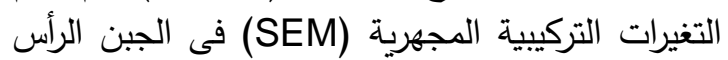

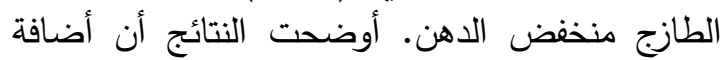
البادئات المنتجة للسكريات العديدة مع خفض الدهن الدهن

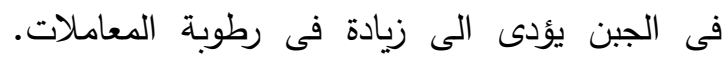

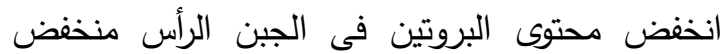

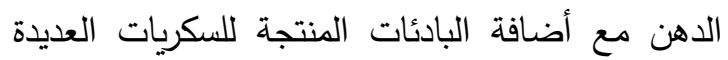

